Institute of $\mathbf{F}_{\text {ood and }} \mathbf{A}_{\text {gricultural }} \mathbf{S}_{\text {ciences }}$

\title{
Some Practical Matters Related to Riviera Soil, Depth to Clay, Water Table, Soil Organic Matter, and Swingle Citrumelo Root Systems ${ }^{1}$
}

\section{Bill Castle, Mace Bauer, Brian Boman and Tom Obreza²}

A topographical overview of the Florida citrus industry readily shows that the most challenging area to grow citrus is the Indian River region. Citrus on the Central Ridge is grown at relatively high elevations and in moderately- to well-drained sandy soils. However, in the South Florida Flatwoods, the land and soils present an entirely different set of largely unfavorable conditions for growing citrus trees. In the flatwoods, there are three landscape positions where citrus groves are normally located: 1 ) flatwoods, the most desirable location because it occupies the highest elevation in the landscape; 2) sloughs; or 3) depressions, the least desirable position. Many groves in the Gulf region are located in flatwoods sites while groves in the Indian River region are commonly located in slough and depressional sites.

Trees on Swingle have relatively problem-free lives in the Gulf area as compared to significant decline problems that occur among trees usually less than 8 years old on the soils of the Indian River region. It is apparent that this difference is strongly related to soil and site characteristics. This is a widespread problem with Swingle, so we began an investigation to better understand flatwoods sites and rootstock behavior. Our real goal is to eventually develop enough information to recommend rootstocks based on the soils in which they will be grown.

Our attention has been focused primarily on the Indian River region where trees on Swingle grow fine for about 5 to 8 years then suddenly decline in certain places. Often only patches of trees decline. A small survey in St. Lucie County showed that Swingle decline was not the result of calcareous soils, but was associated with particular soil series and other site conditions. Several field situations were obvious: (1) pockets of decline in whole areas planted to Swingle where the USDA Soil Survey indicates only one soil series; (2) areas of one soil series planted to trees on several rootstocks, but only those on Swingle are declining; and, (3) areas where trees on Swingle are

1. This document is Fact Sheet HS-894, one of a series of the Horticultural Sciences Department, Florida Cooperative Extension Service, Institute of Food and Agricultural Sciences, University of Florida. Published December 2002. This research was supported by the Florida Agricultural Experiment Station, a FCPRAC grant 002-01I, and from private contributions of Evans Properties, Inc., and approved for publication as Journal Series No.T-00584. Visit the EDIS Web site at http://edis.ifas.ufl.edu.

2. Bill Castle, professor, Horticultural Sciences Department, Citrus REC, Lake Alfred, FL; Mace Bauer, project manager, Indian River REC, Ft. Pierce, FL; Brian Boman, associate professor, Agricultural and Biological Engineering Department, Indian River REC, Ft. Pierce, FL; Tom Obreza, professor, Soil and Water Science Department, Gainesville, FL; Cooperative Extension Service, Institute of Food and Agricultural Sciences, Unviersity of Florida, Gainesville, 32611.

The Institute of Food and Agricultural Sciences is an equal opportunity/affirmative action employer authorized to provide research, educational information and other services only to individuals and institutions that function without regard to race, color, sex, age, handicap, or national origin. For information on obtaining other extension publications, contact your county Cooperative Extension Service office. Florida Cooperative Extension Service/Institute of Food and Agricultural Sciences/University of Florida/Christine Taylor Waddill, Dean. 
planted across several soil series but decline is present only on particular soils.

\section{Why Do Trees on Swingle Decline?}

We decided to study a few sites intensively to answer this question and selected Riviera soil which is the most common soil series (14\%) in St. Lucie County. Riviera, Pineda, and Winder are usually found in sloughs. About $70 \%$ of all citrus trees in St. Lucie and Indian River Counties are growing in one of these three soils. After collecting soil chemical and physical data, and measuring tree size, soil electrical conductivity, and depth to the clay (argillic) layer in Riviera soil, we decided to look underground at the root systems. In early March, we took a small backhoe and excavated trenches between adjacent trees from the furrow out past the tree dripline to near the crown of double-row beds at several sites (Fig. 1). At each site, the soil profile and root system reference points were the tree row.

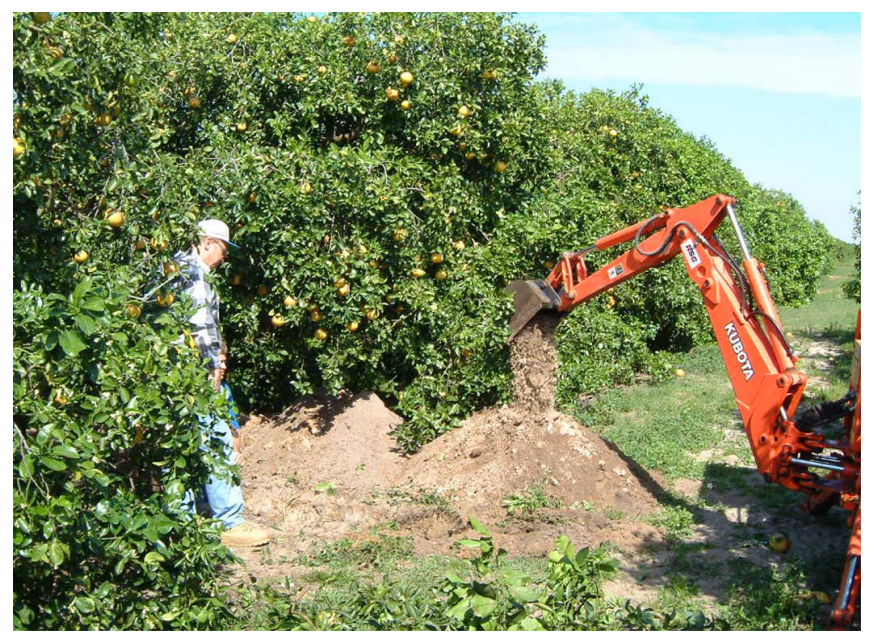

Figure 1. Opening a root system observation trench with a backhoe.

The natural soil profile is relatively undisturbed at the tree row and is typically similar to the one shown in Fig 2. It consists of a surface A horizon that is a dark grayish brown, about 5 inches thick, and generally has no more than about $2 \%$ organic matter. The E horizon is a highly leached, light colored sand. The B horizon is a sandy clay loam and occurs between a depth of 20 to 40 inches. The $\mathrm{C}$ horizon is a mineral layer that has been affected little by soil-forming processes and does not have properties typical of the overlying horizon.

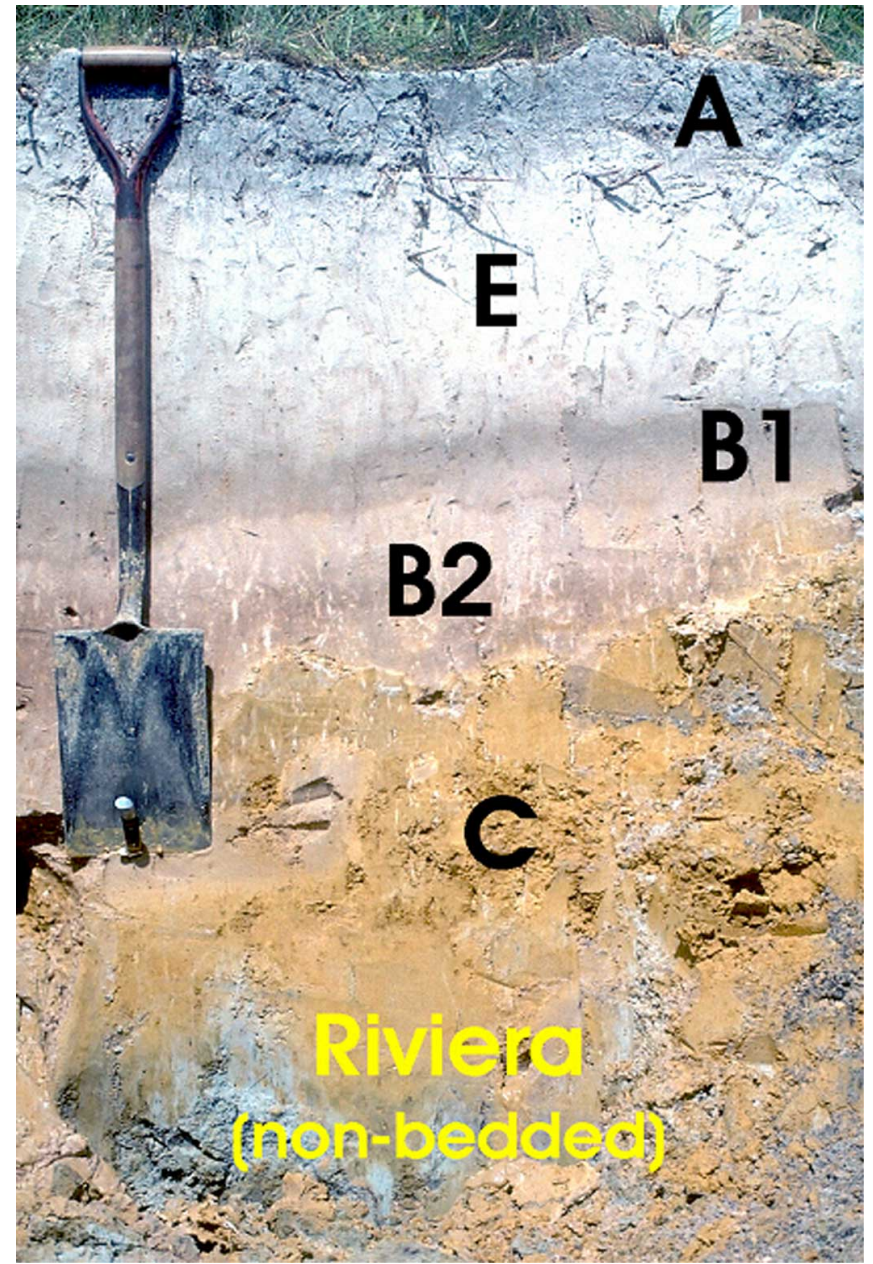

Figure 2. Profile horizons in a typical undisturbed Riviera series soil.

Site A was a 30-acre block planted for the first time in 1987 with Redblush grapefruit trees on Swingle citrumelo rootstock spaced $15 \times 25$ feet in double-row beds and flood irrigated. There were no readily apparent differences in the soil throughout the block. The depth to the clay layer was about 40 inches, and the organic matter content was low. Nevertheless, there were 14-foot tall, normal trees on the west end that graded off to smaller, less healthy-looking 6-foot tall trees at the east end. Our observation trench among a pair of west-end trees was about 3 feet deep at the tree row with little fill over the natural profile. The tree row was elevated about 12 inches above the furrow; the bed crown was about 20 inches above the furrow.

Roots were distributed horizontally from about 4 to 5 feet on the furrow side of the trees to about 12 feet toward the middle of the bed (Fig. 3), and vertically from about 5 inches deep near the furrow to 
12 to 18 inches deep at the tree row and beyond (Fig. 4). Virtually all roots were in the original A horizon plus some in the fill above this layer. In the area of the smaller trees, the soil was lighter in color, with fewer roots, and horizontal root spread was much reduced compared to the west-end trees (Fig. 5). The relative elevation differences between the furrow, tree row and bed crown were the same.

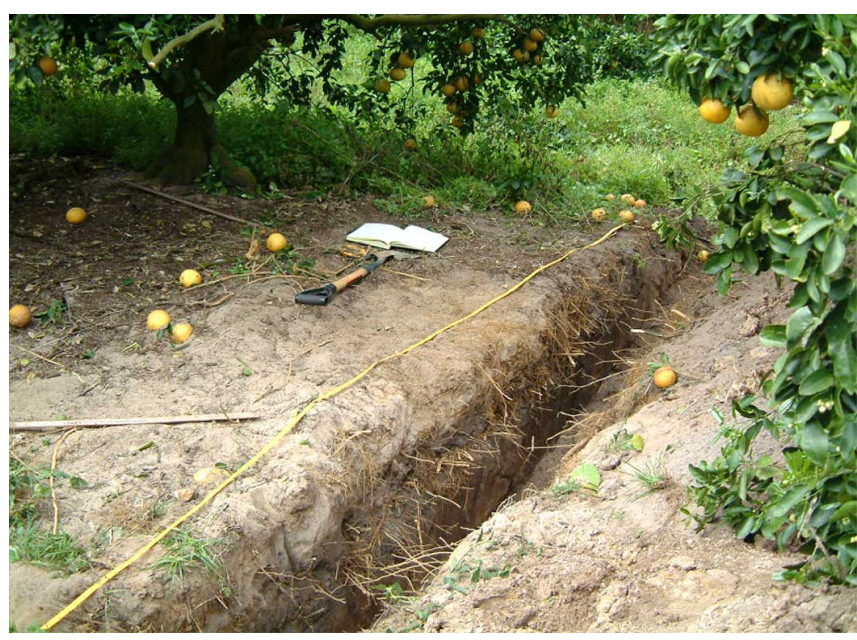

Figure 3. Root systems of "good" 15-year-old Redblush grapefruit trees on Swingle citrumelo rootstock grown on a double-row bed in Riviera soil. The view is from the bed crown toward the furrow.

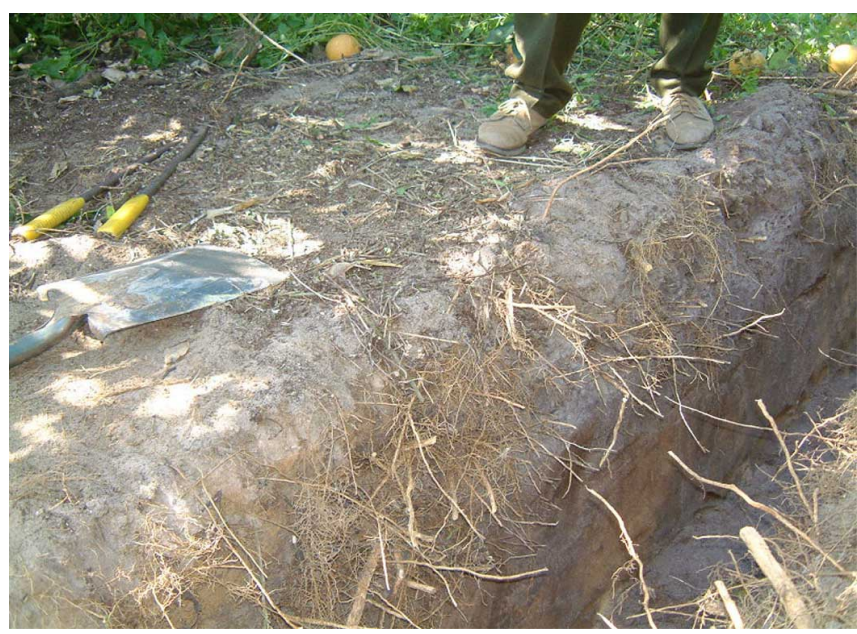

Figure 4. A view into the root trench of the "good" 15-year-old grapefruit trees showing the large number of fibrous and woody roots at the surface with few roots in the E horizon.

At Site B, Hamlin on Swingle trees had been planted in 1989 at $10 \times 25$ feet in double-row beds and were microsprinkler irrigated. Trees in the "good" areas of this block were about 4 feet taller than those in the "poor" areas, but both sets of trees had a healthy appearance and were flushing at the time of

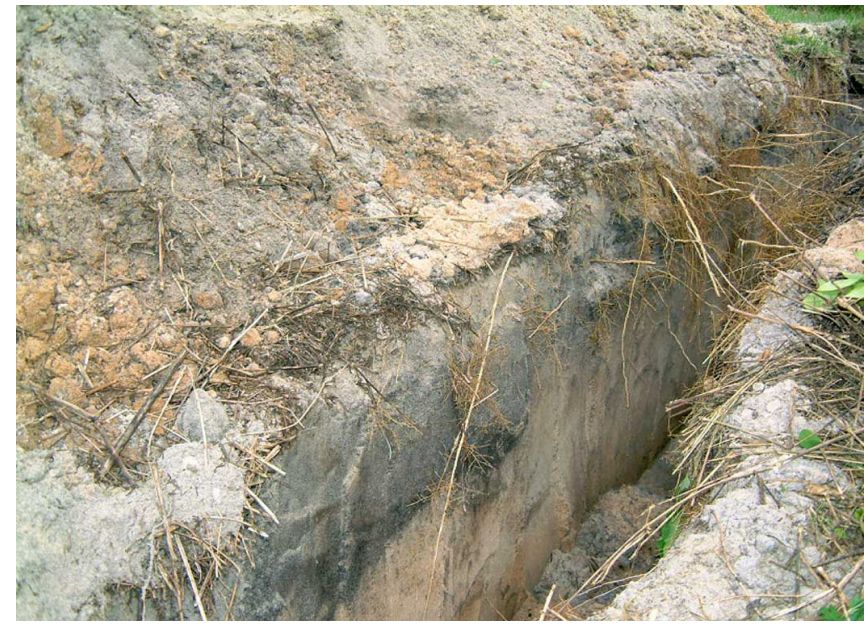

Figure 5. A view from the bed crown toward the furrow of 15-year-old grapefruit trees growing in the "poor" area of a Riviera soil site.

trenching. Our observations were essentially identical to those of Site A: the soil was a darkish color in the trench between "good" trees with an even spread of the root system from the furrow to out beyond the canopy dripline toward the bed crown (Fig. 6). The soil at the "poor"-tree location was lighter colored and the root system was spread out evenly but there were markedly fewer roots (Fig. 7). Again, very few roots were growing in the $\mathrm{E}$ horizon at either location. In the tree row at the "poor" location, a few inches of white sand had been transported from the furrow during bed construction and deposited over the natural soil profile. There were few roots growing in this material.

Near the "poor" trees was a patch of Wabasso soil, a spodosol, where the trees were a little larger. The spodic (organic) layer was 25 inches below the surface at the tree row. There were fibrous and large roots everywhere down to and in the organic layer (Fig. 8); however, there appeared to fewer roots than the quantity we observed among the Swingle trees growing in the "good" location at this site.

Site C was planted for the first time in 1991 with Marsh grapefruit trees on various experimental rootstocks at $14 \times 22.5$ feet with microsprinkler irrigation and occasional flood irrigation. There were nine double-row beds next to each other; eight beds were planted with trees of only one rootstock on each bed. In 2000, the bed of trees on Swingle began to decline. The trees were removed in the spring of 2002. 


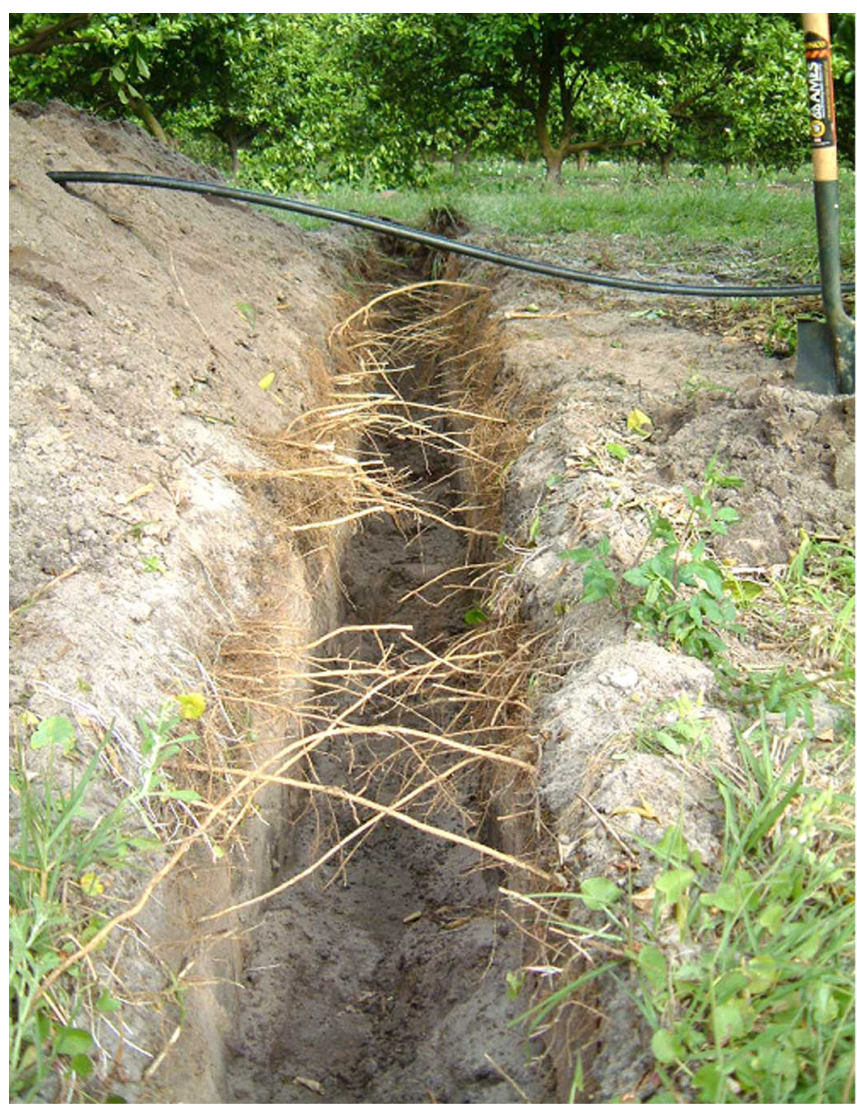

Figure 6. Root systems of "good" 13-year-old Hamlin trees on Swingle citrumelo rootstock grown on a double-row bed in Riviera soil. The view is from the furrow toward the bed crown.

Tree height varied along the Swingle bed and was strongly related to depth to the clay layer unlike at Site A. The tallest trees grew where the depth was the greatest. The shortest trees were located on the bed where the depth to the clay was shallowest which is also where tree decline first appeared. When we dug our root observation trench among the short trees, they had already declined substantially and there were few roots (Fig. 9). When the trench was opened, there was an odor of hydrogen sulfide indicating wet conditions and decay of organic matter. Small amounts of hydrogen sulfide easily kill citrus roots. The soil consisted of a gray surface layer with a light (buff)-colored $\mathrm{E}$ horizon beneath the surface. What distinguished this location was the presence of a thin, dark brown organic layer between the A and E horizons (Fig. 10) that had a feel more like decaying roots than the type of organic matter normally found in a Riviera soil profile.

Next to the Swingle trees was a bed of trees on Sun Chu Sha (SCS) mandarin. The changes in tree

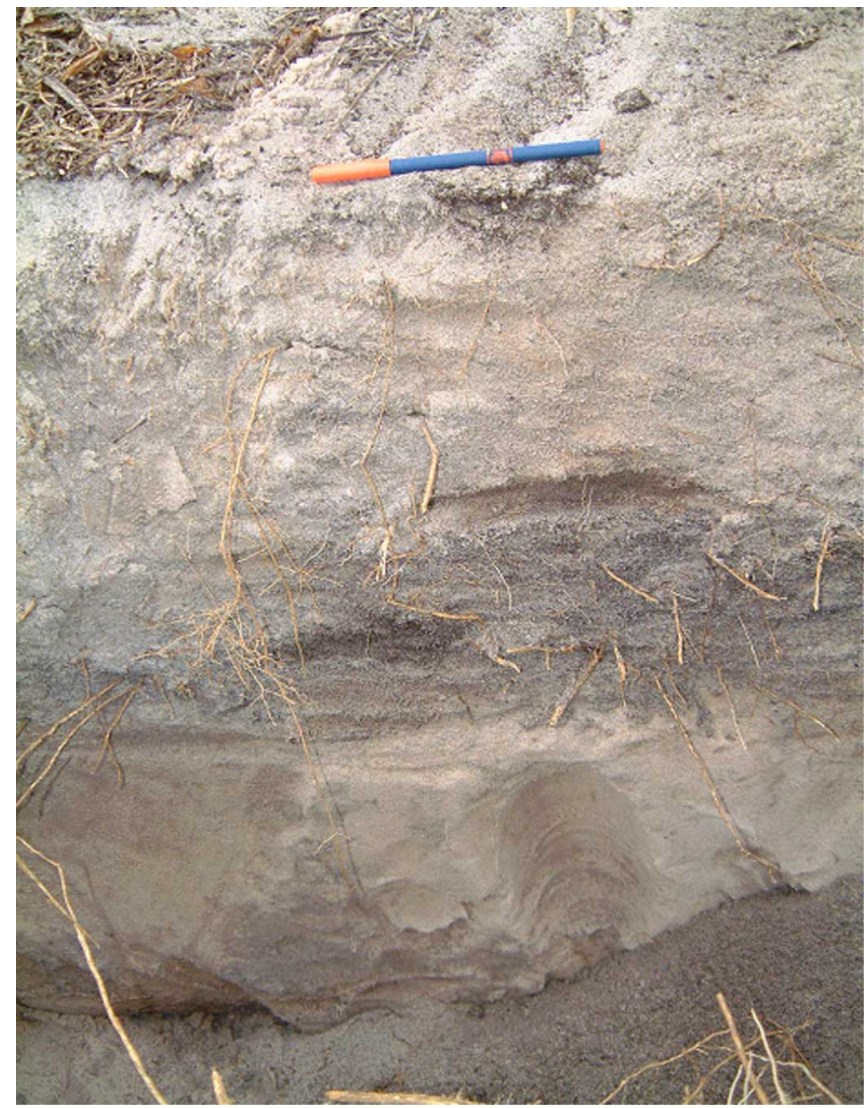

Figure 7. A view into the trench of the 13-year-old Hamlin trees growing in the "poor" area and showing the presence of roots mostly in the A horizon and the absence of roots elsewhere in the profile.

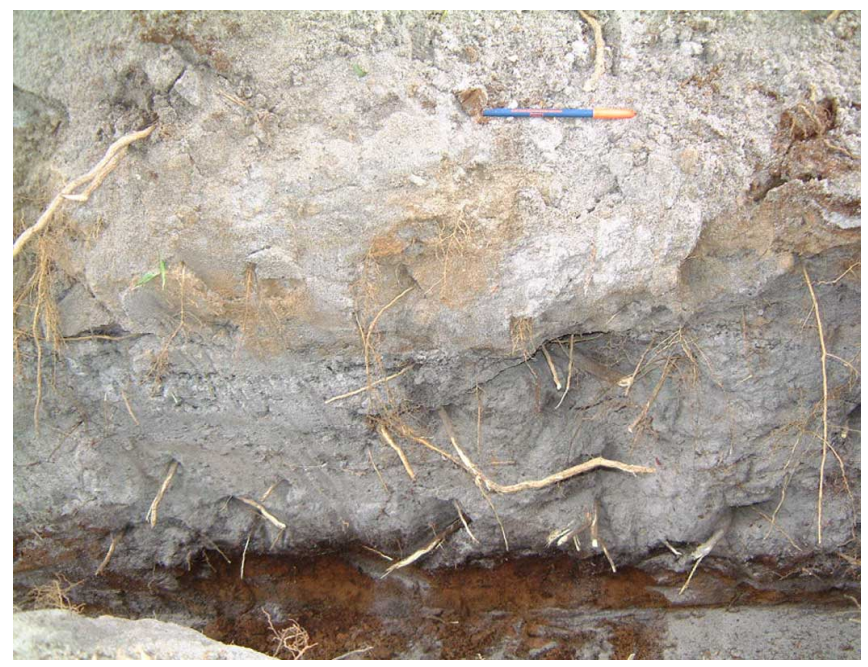

Figure 8. A view into the trench of 13-year-old Hamlin trees on Swingle growing in Wabasso soil. The spodic layer is evident at the bottom of the profile. Roots are present from the surface to the spodic layer.

height along the bed were similar for both sets of trees. In the area where the trees on Swingle were small, so were the trees on SCS although they appeared to be in good health with better developed 


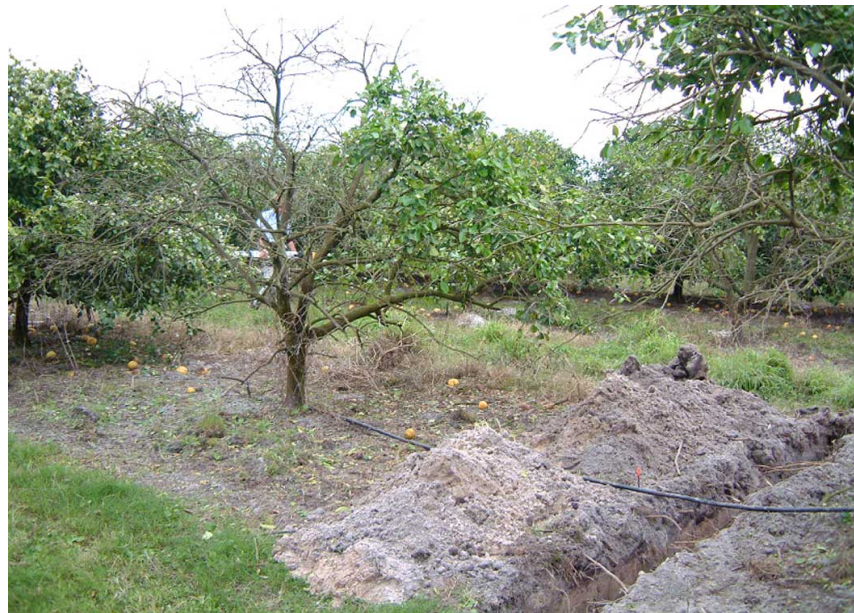

Figure 9. Root systems of 11-year-old Marsh grapefruit trees on Swingle rootstock grown on a double-row bed in a "poor" area of Riviera soil.

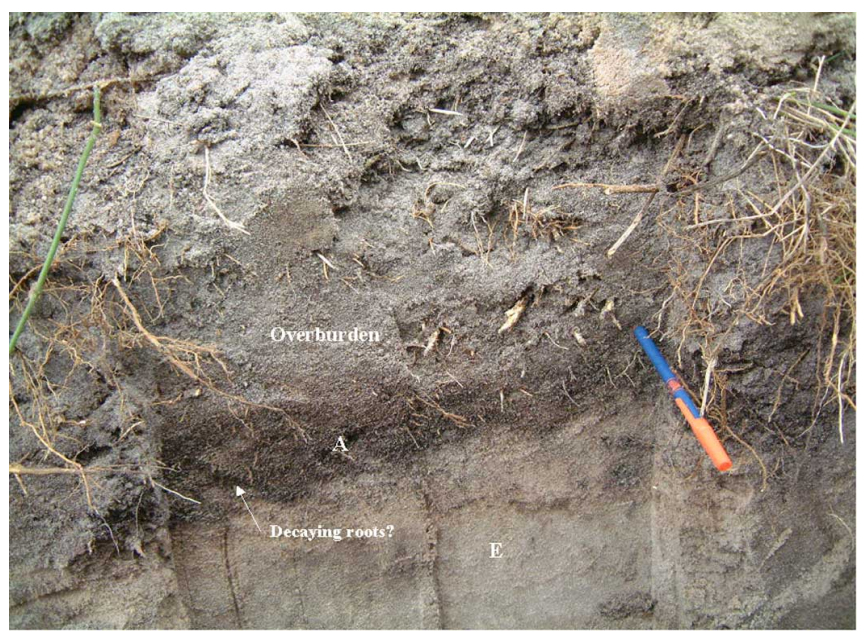

Figure 10. Soil profile of the "poor" Marsh grapefruit trees showing the overbuden, original A horizon, an unnatural organic layer, and the $\mathrm{E}$ horizon.

root systems (Fig. 11) The trees on SCS seemed to be better adapted to the "poor" conditions than those on Swingle perhaps because of inherent differences in their root systems. Among the best trees on either rootstock, there were more roots under the SCS trees (Fig. 12).

\section{What Did We Learn?}

In Riviera soil, Swingle roots developed almost exclusively in A horizon material regardless of whether this material was part of an undisturbed profile or was shifted to a new location during bed construction. This was a consistent observation across several sites. Also, the horizontal root distribution was divided such that about two-thirds

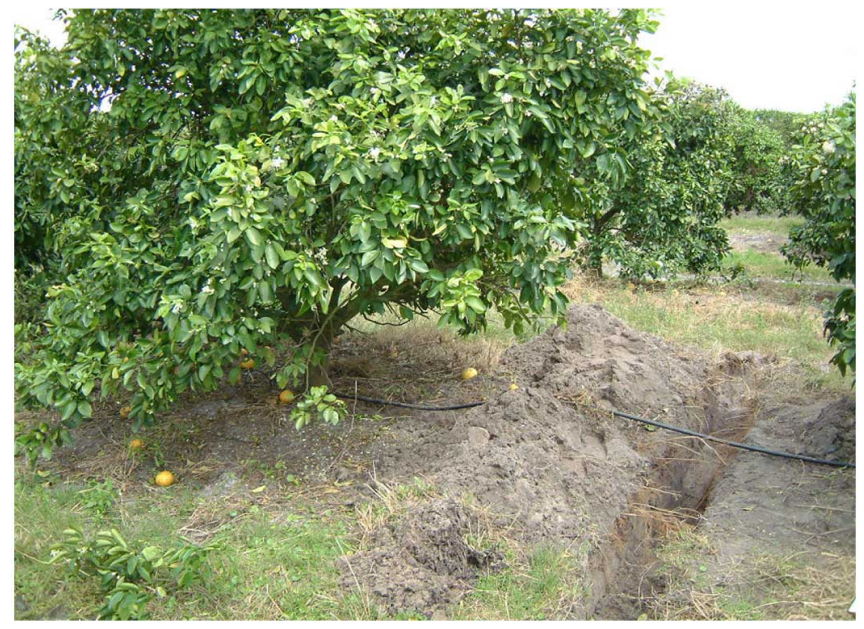

Figure 11. Root system and canopy condition of 11-year-old Marsh grapefruit trees on Sun Chu Sha growing adjacent to the "poor" trees on Swingle. The view is from the furrow toward the bed crown.

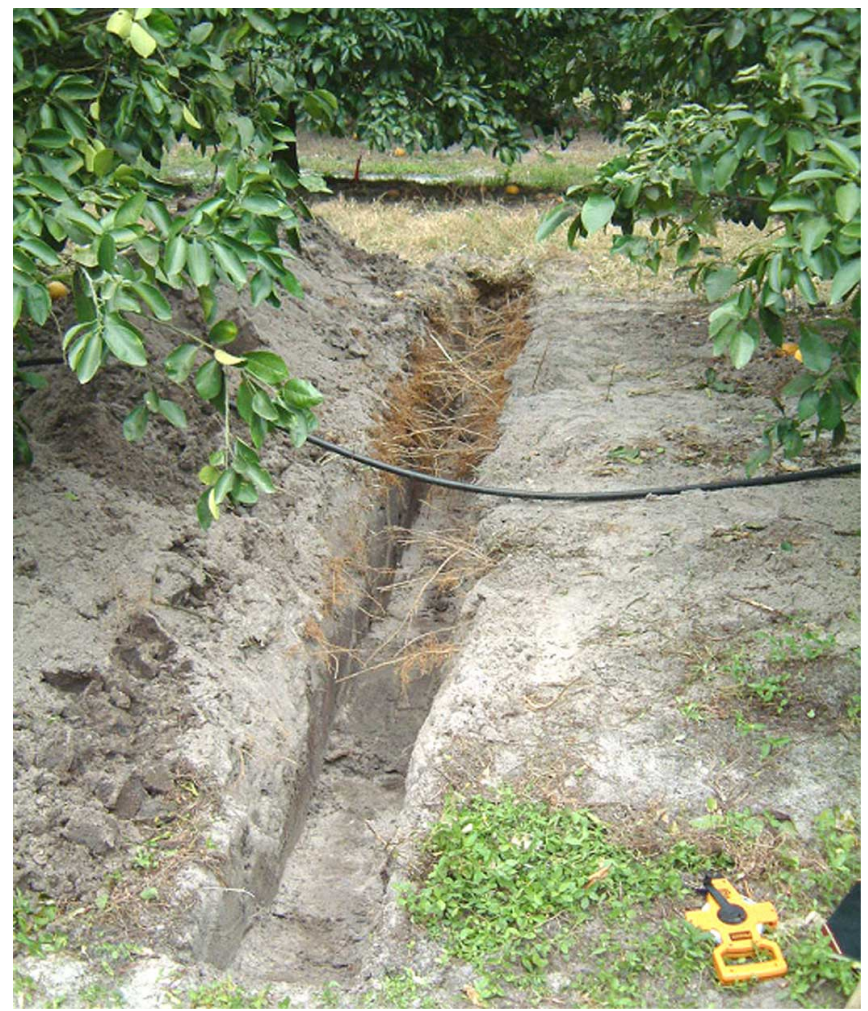

Figure 12. Root systems of "good" 11-year-old Marsh grapefruit trees on Sun Shu Sha. The view is from the furrow toward the bed crown.

was on the crown side of the trees and one-third on the furrow side. 


\section{Why Didn't Swingle Roots Develop In The Riviera E Horizon?}

We collected soil samples from the zone just below the A, but found nothing suggesting that the upper E horizon is unsuitable for citrus roots.

\section{Why Do Trees on Swingle Seem to Grow Well For About 6 To 8 Years In Riviera Soil Then Decline?}

Perhaps these trees reach some sort of equilibrium with their environment at that age, then they become more susceptible to various stresses like flooding and drought. Our research, including the root study, suggest that depth to clay (as it affects water table levels), soil organic matter content, and rootstock differences are implicated in this matter either individually or in combinations.

Subtle site topographical variations prior to bedding are likely to be important in future tree behavior. This factor may explain the decline of the trees on Swingle at Site C. At the location of the "poor" trees, depth to the clay layer was shallow. A rise in the surface of the water table may have caused fibrous root death (as evidenced by the thin organic zone shown in Fig. 10) in this area while not damaging trees growing where the clay layer is deeper in the profile.

An unexpected observation was that "poor" trees invariably had fibrous roots with few woody roots. The trees growing in "good" sites had a mixture of both kinds of roots. This difference in the types of roots indicates a long-term effect of the environment.

These observations have some practical implications, but like all research projects, there are also some caveats. This first root study focused almost entirely on Swingle citrumelo rootstock and Riviera soil. The general root system observations presented above are probably representative of Swingle and other rootstocks in Riviera soil, but when we looked at trees growing in Wabasso soil, the results were different.

From visits to groves in the Indian River region, trees on Swingle do best when growing in flatwoods-type sites, i.e., the higher elevations, or "ridges." The slough sites where Riviera soil is found are not the most desirable for Swingle. Our root system observations indicate that if you are preparing to plant a grove in Riviera soil, or re-bedding a site of this soil, it would be worthwhile to first gather topographical information and plan accordingly. Absolute elevation data can be obtained using GPS equipment, or relative data can be collected by using standard surveying procedures. A useable depth-to-clay map to identify potential problem spots can be created by coring.

Our limited preliminary information indicates that the clay layer in the Riviera profile may be relatively flat and, thus, it is surface variations that may explain differences in depth to clay within a given site. Therefore, bedding or re-bedding will produce areas with shallow depths to clay. These should be avoided for Swingle. Other rootstock choices might be Smooth Flat Seville, and Kinkoji. Furthermore, we observed a definite link between Swingle root system distribution and the A horizon. Therefore, consideration should be given to the placement and preservation of this material when constructing beds.

The horizontal and vertical spread of the root system also imply irrigation practices designed to maintain proper soil water content in the root zone and not below. It is also questionable whether drip irrigation can supply adequate water to such widespread root systems. Irrigation practices should preclude raising the water table into the root zone for any extended period of time. Additional study may demonstrate that Swingle is not very tolerant of wet conditions, especially chronically wet ones that would occur in those low areas of a Riviera site.

\section{Final Question: Should Swingle Citrumelo Rootstock Be Used At All On Riviera Soil?}

This is a fair question. There is enough evidence showing that trees on Swingle can perform well on this soil series. Perhaps there is enough variation within Riviera sites such that there are some locations actually acceptable, if not suitable, for Swingle. 